\title{
ANALISIS KURIKULUM PENDIDIKAN AGAMA ISLAM PRA DAN PASCA UNDANG-UNDANG RI NOMOR 20 TAHUN 2003 TENTANG SISTEM PENDIDIKAN NASIONAL
}

\author{
Asfiati \\ Fakultas Tarbiyah dan IImu Keguruan Institut Agama Islam Negeri \\ Padangsidimpuan \\ Jalan T. Rizal Nurdin KM. 4,5 Sihitang Padangsidimpuan \\ E-mail: asfiati@yahoo.co.id
}

\begin{abstract}
Abstrak
Kurikulum sangat strategis digunakan sebagai pedoman penyelenggaraan kegiatan pembelajaran, yang di dalamnya terdapat panduan interaksi antara guru dan peserta didik. Perkembangan dan pengembangan kurikulum pendidikan agama Islam mengacu pada perubahan bidang dan materi pelajaran serta perubahan waktu, esensi kurikulum dalam aspek tujuan makro pendidikan. Kurikulum pendidikan agama Islam Pasca Undang-Undang RI Nomor 20 Tahun 2013 tentang Sistem Pendidikan Nasional ikut berperan penting dalam mengakui pentingnya pendidikan moral bangsa dan nilai-nilai kultural budaya berdasarkan nilai-nilai moral dan kaedah-kaedah yang berketuhanan Yang Mahaesa.
\end{abstract}

\begin{abstract}
The curriculum is very strategically used as guidelines for the implementation of learning activities, which included a guide to the interaction between teachers and learners. Development and curriculum development in Islam refers to the changes in the field and the subject matter as well as the change of time, the essence of the curriculum in the educational aspects of the macro objectives. Islamic religious education curriculum Post Undang-Undang RI Nomor 20 Year 2013 on National Education System played a role important in recognizing the importance of moral education and cultural values culture based on moral values and rules that divine principle that is Almighty.
\end{abstract}

Kata Kunci: Kurikulum, Islam, dan Pendidikan 
Asfiati

\section{Pendahuluan}

Negara yang beradab adalah negara yang menjunjung tinggi nilainilai pendidikan. Pendidikan yang diakui dan dilaksanakan secara bersama antara warga dan pemimpin bangsa niscaya menjadikan negara tersebut aman damai dan makmur. Indikator damai, aman dan makmur dapat ditilik dari sudut kondisi kesadaran rakyat dalam mengagungkan pendidikan. Pendidikan yang maju menjadikan setiap warga negara memiliki sikap cinta tanah air dan nasionalisme. Setiap warga negara yang mengisi aktivitas hidupnya demi pendidikan menjadikan bangsa tersebut kaya dan maju.

Kemajuan pendidikan suatu bangsa terletak atas dasar pemikiran yang mau untuk membesarkan bangsa. Pemikiran para pemerhati pendidikan dapat dituangkan dalam peraturan dan Undang-Undang Sistem Pendidikan Nasional yang mengatur seluruh ranah pendidikan untuk kemajuan bangsa. Undang-Undang Sistem Pendidikan Nasional mengatur tentang banyak hal mulai dari tata aturan perundang-undangan pendidik, peserta didik, manajemen pendidikan hingga tujuan pendidikan. Indonesia telah mengalami banyak perubahan Undang-Undang Sistem Pendidikan Nasional mulai tahun 1950 hingga saat ini masih tetap berlaku UndangUndang Sisdiknas No.20 Tahun 2003. Perubahan Undang-Undang Sistem Pendidikan Nasional tersebut membuktikan bahwa bangsa Indonesia peduli dan peka terhadap pendidikan. Demikian halnya terhadap kurikulum. Pendidikan sebagai sistem dapat bergerak maju dengan berkembang karena subsistem pendidikan itu sendiri dijalankan sesuai dengan kode etik pendidikan. Salah satu sub sistem yang dimaksud adalah kurikulum. Kurikulum yang disusun dan direncanakan dipandu oleh Undang-Undang Sistem Pendidikan Nasional (UU Sisdiknas) No. 20 tahun 2003 bab X Pasal 36 ayat 3 berbunyi:

Kurikulum disusun sesuai dengan jenjang pendidikan dalam kerangka Negara Kesatuan Republik Indonesia dengan memperhatikan: a. peningkatan iman dan takwa; b. peningkatan akhlak mulia; c. peningkatan potensi, kecerdasan dan minat peserta didik; d. keragaman potensi daerah dan lingkungan; e. tuntutan pembangunan daerah dan nasional; f. tuntutan dunia kerja; g. perkembangan ilmu pengetahuan dan teknologi dan seni; $h$. 
agama; i. dinamika perkembangan global; dan j. persatuan nasional dan nilai-nilai kebangsaan. ${ }^{1}$

Kurikulum menurut Undang-Undang No 20 tahun 2003 tersebut mencerminkan bahwa banyak aspek yang perlu diperhatikan dalam menyusun kurikulum yang kesemuanya harus disesuaikan dengan jenjang pendidikan dalam kerangka Negara Kesatuan Republik Indonesia, berarti adanya standar nasional. Setiap lembaga pendidikan yang mengelola proses belajar mengajar harus sesuai dengan standar nasional pendidikan. Standar nasional adalah capaian yang menyeluruh oleh setiap peserta didik sehingga mampu mengikuti skala nasional, tanpa membedakan daerah, wilayah, jenis dan jenjang pendidikan.

Dengan demikian kurikulum yang berlaku di setiap wilayah bumi Indonesia memperhatikan kondisi peserta didik sebagai warga negara dan harus sesuai dengan standar nasional pendidikan. Untuk itu kurikulum harus sesuai dengan pengalaman, dinamika pengetahuan, teknologi, seni dan sikap pengembangan diri peserta didik. Sikap pengembangan diri peserta didik cenderung merupakan tugas kurikulum Pendidikan Agama Islam. Guna menyikapi keadaan dan harapan bangsa terhadap kurikulum penting kiranya menganalisis perkembangan kurikulum Pendidikan Agama Islam pra dan pasca Undang-Undang RI Nomor 20 Tahun 2013 tentang Sistem Pendidikan Nasional, yang diawali dari perkembangan kurikulum di Indonesia.

\section{Perkembangan Kurikulum di Indonesia Pra dan Pasca Undang-Undang Nomor 20 Tahun 2003 tentang Sistem Pendidikan Nasional}

Indonesia adalah negara yang kaya dengan dinamika, khasanah dan pertumbuhan. Dalam bidang pendidikan Indonesia telah diakui mampu mensejajarkan diri dengan pendidikan di negara lainnya. Hal ini terbukti dari sumber daya pendidikan yang mampu mengutus peserta didik untuk

'Departemen Agama RI, Direktorat Jenderal Kelembagaan Agama Islam, Memahami Paradigma Baru Pendidikan Nasional dalam Undang-Undang Sisdiknas (Jakarta: Depag RI, 2003), hlm. 50. 
mengikuti beberapa event olimpiade ilmu pengetahuan baik dari bidang ilmu-ilmu eksakta dan non eksakta. Indonesia mampu mengikuti perkembangan kemajuan pendidikan dunia karena seluruh warga negara Indonesia sama-sama bertanggung jawab dalam menyelenggarakan pendidikan. Penyelenggaraan pendidikan dilakukan dengan tata cara pengelolaan pendidikan sesuai dengan peraturan dan kewenangan bangsa. Indikator penyelenggaraan pendidikan dapat dilihat dari beberapa aspek, antara lain dari perkembangan kurikulum.

Kurikulum sebagai aset dan indikator dalam menyelenggarakan pendidikan telah berhasil melakukan perkembangan mulai dari sentralisasi, desentralisasi serta otonomi terhadap pendidikan selalu mengalami inovasi. Perkembangan kurikulum tidak terlepas dari usaha pemerintah, pelaksana pendidikan dan masyarakat demi tercapainya tujuan bersama yang diinginkan. Hal ini diharapkan dapat menjadi solusi awal dalam mengatasi rendahnya kualitas proses dan hasil pendidikan di Indonesia yang berakibat pada rendahnya rata-rata kualitas sumber daya manusia Indonesia dalam konteks persaingan regional dan global.

Perkembangan kurikulum di Indonesia mulai tahun 1947, hingga saat ini tahun 2013 adalah bukti sejarah bahwa Indonesia memberikan perhatian penuh terhadap pendidikan. Terjadinya perkembangan kurikulum yang berlangsung di Indonesia membuktikan bahwa Indonesia mengikuti setiap jejak perubahan zaman. Salah satu indikator perubahan zaman dari aspek pendidikan adalah perkembangan kurikulum dilakukan dengan pengembangan kurikulum yang bersifat mencapai keberhasilan dan kemajuan pendidikan. Perkembangan kurikulum yang dimaksud sesuai dengan potensi peserta didik, kemajuan bangsa dan negara, teknologi yang mutakhir serta kehidupan keberbangsaan yang menyeluruh dan merata dalam ikatan nasionalisme.

Adapun faktor-faktor perkembangan kurikulum di Indonesia disebabkan antara lain:

a. Menyesuaikan dengan perkembangan zaman, hal ini dapat kita lihat awal perubahan kurikulum dari rencana pelajaran 1947 menjadi rencana pelajaran terurai 1952. Awalnya hanya mengikuti atau meneruskan 
kurikulum yang ada kemudian dikembangkan lagi dengan lebih menfokuskan pelajaran dengan kehidupan sehari-hari.

b. Kepentingan politis semata, hal ini sangat jelas terekam dalam pengembangan kurikulum 2004 Kurikulum Berbasis Kompetensi (KBK) menjadi kurikulum 2006 Kurikulum Tingkat Satuan Pendidikan (KTSP). Secara matematis masa aktif kurikulum 2004 sebelum dirubah menjadi kurikulum 2006 hanya bertahan selama 2 tahun. Hal ini tidak sesuai dengan perkembangan sebelumnya. Dalam kurun waktu yang singkat ini, kita tidak bisa membuktikan baik tidaknya sebuah kurikulum.

c. Tujuan filsafat pendidikan nasional yang dijadikan sebagai dasar untuk merumuskan tujuan institusional yang pada gilirannya menjadi landasan merumuskan tujuan kurikulum suatu satuan pendidikan.

d. Sosial budaya yang berlaku dalam kehidupan masyarakat

e. Keadaan lingkungan (interpersonal, kultural, biokologi, geokologi).

f. Kebutuhan pembangunan Politik, Sosial, Budaya, Pertahanan dan Keamanan (POLISOSBUDHANKAM).

g. Perkembangan ilmu pengetahuan dan teknologi yang sesuai dengan sistem nilai dan kemanusiaan serta budaya bangsa. ${ }^{2}$

Dari masing-masing perkembangan kurikulum yang dialami masyarakat Indonesia mulai dari kondisi politik, filsafat, sosial budaya, senantiasa mengarah kepada perbaikan dari aspek moralitas dan keberagamaan. Perkembangan kurikulum pendidikan di Indonesia menilik kepada kehidupan dan potensi peserta didik itu sendiri. Kehidupan peserta didik sesungguhnya bukanlah hal yang stagnan dan labil, akan tetapi lebih berkarya dan berguna dalam mengikuti pola perkembangan kehidupan. Perkembangan kurikulum selalu mengupayakan adanya perkembangan suasana pembelajaran yang variatif. Kemudian pengembangan pembelajaran yang bersifat kondusif dan efektif. Proses pencapaian perkembangan pendidikan yang dinamis serta pengembangan pendidikan yang aplikatif sesungguhnya dapat dicapai dengan membangun kondisi

2E.Mulyasa, Pengembangan dan Implementasi Kurikulum 2013 (Bandung: Remaja Rosdakarya: 2013), hlm. 22. 
Asfiati

melalui kurikulum Pendidikan Agama Islam. Kurikulum Pendidikan Agama Islam yang menjadikan ajaran agama Islam itu sebagai suatu pandangan hidup guna mencapai keselamatan dan kesejahteraan hidup di dunia maupun hidup di akhirat.

Kurikulum Pendidikan Agama Islam merupakan mata pelajaran yang dikembangkan dari ajaran-ajaran dasar yang terdapat dalam agama Islam. Ajaran-ajaran dasar tersebut terdapat dalam al-Quran dan Hadits. Pendidikan Agama Islam bertujuan meningkatkan keimanan, pemahaman, penghayatan dan pengamalan peserta didik tentang agama Islam sehingga menjadi manusia yang beriman dan bertakwa kepada Allah Swt serta berakhlak mulia dalam kehidupan pribadi, bermasyarakat, berbangsa dan bernegara. Kurikulum Pendidikan Agama Islam diajarkan pada lembaga pendidikan formal sebagai kegiatan yang dilakukan guru untuk mencapai keberhasilan dalam memperkuat iman dan ketakwaan peserta didik terhadap Tuhan Yang Maha Esa.

Untuk itu disimpulkan bahwa perkembangan kurikulum melalui kurikulum Pendidikan Agama Islam diharapkan dapat menghantarkan peserta didik lebih terarah, memiliki nilai-nilai luhur, penuh etika dan mempunyai tanggung jawab moral yang tinggi. Untuk melihat lebih jelas perkembangan kurikulum di Indonesia yang mengembrio lahirnya kurikulum Pendidikan Agama Islam dapat ditelusuri sejak tahun 1947 hingga sekarang.

\section{Kurikulum Tahun 1947 Rencana Pembelajaran}

\section{Konsep Kurikulum tahun 1947}

Adapun konsep kurikulum 1947 menekankan pada pembentukan karakter manusia yang berdaulat dan sejajar dengan bangsa lain. Karakter manusia menyangkut tentang nilai-nilai luhur yang dimiliki setiap peserta didik. Karakter adalah kualitas mental atau moral, kekuatan moral, nama baik atau reputasi, dan karakter itu sendiri merupakan ciri khas yang dimiliki suatu benda atau individu. Ciri khas tersebut adalah asli dan mengakar pada 
kepribadian individu dan merupakan mesin pendorong bagi seseorang bertindak, bersikap, berujar, dan merespon sesuatu. ${ }^{3}$

\section{Tujuan Kurikulum Tahun 1947}

Tujuan kurikulum 1947 adalah untuk memberikan kesempatan secara menyeluruh kepada rakyat Indonesia memperoleh pendidikan dan pengajaran tanpa kecuali. Hal ini dirasakan masyarakat Indonesia di mana tidak ada diskriminasi dalam memperoleh pendidikan. Warga negara Indonesia dari golongan bangsawan dan pribumi mendapat kesempatan yang sama dalam memperoleh pendidikan dan pengajaran. Bila dianalisis tujuan kurikulum 1947 ini terdeteksi bahwa kurikulum Pendidikan Agama Islam telah diperhatikan yakni adanya kesempatan bersama dalam memperoleh pendidikan. Kesempatan tersebut dianalogikan bahwa setiap manusia berhak mendapat pendidikan dan pengajaran.

\section{Kurikulum Tahun 1952 Rencana Pelajaran Terurai}

\section{Konsep kurikulum Tahun 1952}

Tahun 1952 kurikulum Indonesia mengalami penyempurnaan. Dengan berganti nama menjadi rencana pelajaran terurai 1952. Ciri kurikulum 1952 yang dijadikan sebagai konsep kurikulum adalah setiap pelajaran harus memperhatikan isi pelajaran yang dihubungkan dengan kehidupan sehari-hari. Konsep tujuan kurikulum 1952 membuktikan bahwa pendidikan agama Islam terbangun, di mana isi pelajaran yang dihubungkan dengan kehidupan sehari-hari sesuai dengan nilai-nilai dan moral bangsa. Isi pelajaran yang dikaitkan dengan kehidupan sehari-hari yaitu berkonotasi pada perilaku dan budi pekerti sehingga nilai-nilai pendidikan agama Islam dapat diterapkan dalam setiap sikap dan perbuatan peserta didik.

Peserta didik diharapkan mampu mengaplikasikan isi pelajaran yang mempunyai orientasi nilai-nilai kemanusiaan dalam setiap tingkah laku baik di lingkungan sekolah, keluarga dan masyarakat hingga di lingkungan manca negara.

\section{Tujuan Kurikulum Tahun 1952}

${ }^{3}$ Abdul Majid dan Dian Andayani, Pendidikan Karakter Perspektif Islam (Bandung: Remaja Rosdakarya, 2012), hlm. 11. 
Berawal dari materi pelajaran yang dituangkan kurikulum 1952, maka arah dan tujuan kurikulum 1952 memuat tentang pencapaian keberhasilan dalam mengisi kemerdekaan. Arah kurikulum 1952 menuju kepada pendidikan kebangsaan yang berupaya mengisi kemerdekaan. Adapun tujuan kurikulum 1952 adalah menciptakan masyarakat Indonesia sebagai peserta didik yang mempunyai jati diri sesuai dengan nilai-nilai kebangsaan.

Disimpulkan bahwa dari konsep, arah dan tujuan serta materi kurikulum 1952 terkandung nilai-nilai pendidikan agama Islam di mana masyarakat digerakkan untuk berjuang. Dengan demikian pendidikan agama Islam yang dapat dilakukan adalah sikap semangat dalam mengisi kemerdekaan, sikap patriotisme dan tanggung jawab dalam mencapai masyarakat yang handal dan kuat.

\section{Kurikulum Tahun 1964 Rencana Pendidikan}

\section{Konsep Kurikulum Tahun 1964}

Menjelang tahun 1964 pemerintah kembali menyempurnakan sistem kurikulum pendidikan di Indonesia. Kurikulum ini diberi nama rencana pendidikan 1964 yang menjadi ciri dari kurikulum ini pembelajaran dipusatkan pada program pancawardhana yaitu pengembangan moral, kecerdasan, emosional, kerigelan dan jasmani. Program pancawardhana adalah membuktikan nilai-nilai pendidikan agama Islam baik secara jasmani dan rohani seyogyanya ditampilkan dalam hidup dan kehidupan peserta didik.

\section{Tujuan Kurikulum Tahun 1964}

Arah dan tujuan kurikulum 1964 adalah meningkatkan sikap nasionalisme dan cinta tanah air. Tujuan ini diharapkan tercapai dengan melakukan beberapa hal, antara lain peserta didik harus ditanamkan dengan program panca wardhana. Program ini diajarkan kepada setiap peserta didik dalam setiap lembaga dan termasuk mata pelajaran ataupun materi pelajaran kurikulum 1964. Arah dan tujuan kurikulum 1964 membuktikan bahwa terdapat ajaran pendidikan agama Islam, di mana rakyat Indonesia diharapkan mempunyai satu kesatuan politik budaya dan pertahanan 
keamanan yang selalu merujuk kepada Pancasila dan Undang-Undang Dasar 1945.

\section{Kurikulum Tahun 1968}

\section{Konsep Kurikulum Tahun 1968}

Tahun 1968 merupakan pembaharuan dari kurikulum 1964. Yaitu perubahan struktur pendidikan dari pancawardhana menjadi pembinaan jiwa pancasila, pengetahuan dasar, dan kecakapan khusus. Kurikulum 1968 membuktikan rasa nasionalis dan nilai-nilai ajaran agama Islam dikembangkan dalam mengisi kemerdekaan. Peserta didik sudah lebih dituntut untuk menjiwai nilai-nilai luhur bangsa yang berketuhanan Yang Maha Esa, berkemanusiaan yang adil dan beradab, mempunyai kekuatan persatuan Indonesia, memiliki rasa kerakyatan yang dipimpin oleh hikmad kebijaksanaan dalam permusyawaratan perwakilan serta berkeadilan sosial.

\section{Tujuan Kurikulum Tahun 1968}

Arah dan tujuan kurikulum 1968 menitikberatkan kepada kecakapan bangsa yaitu mencari jati diri bangsa. Jati diri tersebut tetap berlandaskan Pancasila dan Undang-Undang Dasar 1945. Bila dikaitkan dengan pendidikan agama Islam bahwa kurikulum 1968 menitikberatkan pada nilainilai luhur bangsa berlandaskan dasar-dasar pokok agama.

\section{Kurikulum Tahun 1975 Sistem PPSI}

\section{Konsep Kurikulum Tahun 1975}

Tahun 1975 sebagai pengganti kurikulum 1968 menekankan pada tujuan, agar pendidikan lebih efisien dan efektif. Pengembangan kurikulum pendidikan agama Islam penting dievaluasi, setelah peserta didik mendapatkan materi pelajaran diharapkan dapat diimplikasikan dalam kebermaknaan kehidupan siswa. Kualitas peserta didik semakin diarahkan sesuai dengan materi dan kegiatan pembelajaran.

Berdasarkan konsep, arah dan tujuan kurikulum 1975 dibuktikan bahwa pendidikan agama Islam menekankan pada kemampuan dasar peserta didik. Peserta didik yang mempunyai potensi dan kemampuan dibimbing sesuai dengan tujuan instruksional setiap mata pelajaran. Nilainilai ajaran agama yang hendak dicapai adalah peserta didik yang mempunyai kemampuan secara utuh dan khusus. 
Asfiati

\section{Kurikulum Tahun 1984 Model CBSA}

\section{Konsep Kurikulum Tahun 1984}

Tahun 1984 mengusung proses skill approach. Kurikulum ini juga sering disebut dengan kurikulum 1984 yang disempurnakan. Posisi peserta didik ditempatkan sebagai subyek belajar. Model ini disebut dengan model cara belajar siswa aktif (CBSA). Setiap yang diperoleh peserta didik harus secara aktif diharapkan diamalkannya. Peserta didik lebih diarahkan memiliki kemampuan dasar yang dikembangkan di lembaga pendidikan.

\section{Tujuan Kurikulum Tahun 1984}

Tujuan dan arah yang hendak dicapai adalah peserta didik yang aktif. Aktif dalam kategorisasi kurikulum pendidikan agama Islam adalah peserta didik yang mempunyai keahlian sendiri untuk dikembangkan dan diberdayakan sehingga dapat dijadikan format yang bagus bagi peserta didik lainnya. Kurikulum 1984 ini sekalipun aspek ilmu dan keahlian ataupun pengembangan pengetahuan lebih ditekankan namun mata pelajaran yang mendukung keahlian tersebut diajarkan sesuai dengan nilai-nilai moral bangsa.

\section{Kurikulum Tahun 1994}

\section{Konsep Kurikulum Tahun 1994}

Tahun 1994 lebih pada upaya memadukan kurikulum-kurikulum sebelumnya. Jiwanya ingin mengkombinasikan antara kurikulum 1975 dan kurikulum 1984, antara pendekatan proses. Salah satu upaya penyempurnaan itu diberlakukannya suplemen kurikulum $1994 .{ }^{4}$

\section{Konsep Kurikulum Tahun 1994}

Konsep kurikulum 1994 lebih cenderung merujuk kepada keikutsertaan peserta didik dalam aktif berbuat di dalam proses pendidikan dan pengajaran. Peserta didik diberikan kesempatan penuh dalam mengembangkan potensi dan keahliannya. Dari konsep proses kurikulum 1994 bertujuan menggali potensi peserta didik sesuai dengan perkembangan bangsa Indonesia. Disimpulkan kurikulum pendidikan agamas Islam dalam kurikulum 1994 menitikberatkan kepada kemampuan

${ }^{4}$ Zainuddin, Reformasi Pendidikan Kritik Kurikulum dan Manajemen Berbasis Sekolah (Yogyakarta: Pustaka Pelajar, 2008), hlm. 186-192. 
dalam berspesialisasi berarti pendidikan dan pengajaran diupayakan bermakna dan bersinergi.

\section{Kurikulum Tahun 2004 KBK}

\section{Konsep Kurikulum Tahun 2004 KBK}

Tahun 2004, pada era ini kurikulum yang dikembangkan diberi nama kurikulum berbasis kompetensi (KBK). Kurikulum ini menitikberatkan pada pengembangan kemampuan melakukan (kompetensi) tugas-tugas dengan standar performasi tertentu, sehingga hasilnya dapat dirasakan oleh peserta didik, berupa penguasaan terhadap seperangkat kompetensi tertentu. Kurikulum berbasis kompetensi merupakan suatu konsep kurikulum yang juga menekankan pendidikan agama Islam di mana perkembangan kemampuan melakukan tugas-tugas pada standar performance tertentu, sehingga hasilnya dapat dirasakan oleh peserta didik berupa penguasaan terhadap seperangkat kompetensi tersebut.

Pengembangan kurikulum pendidikan agama Islam semakin dibuktikan dengan kognitif, afektif dan psychomotorik. Di mana hasil belajar dicapai pada tiga ranah tujuan pendidikan, yaitu: cognitive domain (ranah kognitif), yang berisi perilaku-perilaku yang menekankan aspek intelektual, seperti pengetahuan, pengertian, dan keterampilan berpikir, affective domain (ranah afektif) berisi perilaku-perilaku yang menekankan aspek perasaan dan emosi, seperti minat, sikap, apresiasi, dan cara penyesuaian diri, psychomotor domain (ranah psikomotor) berisi perilaku-perilaku yang menekankan aspek keterampilan motorik seperti tulisan tangan, mengetik, berenang, dan mengoperasikan mesin komputer.

\section{Tujuan Kurikulum Tahun 2004 KBK}

Tujuan diterapkan kurikulum berbasis kompetensi (KBK) di Indonesia adalah untuk mendongkrak mutu outcomes pendidikan dengan cara memberdayakan sekolah/madrasah dalam mengembangkan kompetensi yang akan diberikan pada anak didik sesuai dengan kondisi lingkungannya.

Kurikulum berbasis kompetensi (KBK) didesain dengan menggunakan prinsip-prinsip pengembangan sebagai berikut:

a. Peningkatan keimanan, budi pekerti luhur, dan penghayatan nilai-nilai budaya. Sesuai dengan tujuan pendidikan nasional yaitu membentuk 
manusia yang beriman dan bertakwa sejalan dengan filsafat bangsa, maka peningkatan keimanan dan pembentukan budi luhur merupakan prinsip pertama yang harus diperhatikan oleh para pengembang kurikulum berbasis kompetensi (KBK) di lapangan. Dengan demikian, prinsip ini harus digali, dipahami dan ditanamkan sehingga mewarnai proses pengembangan kurikulum.

b. Keseimbangan etika, logika, estetika dan kinestika. Pembentukan manusia seutuhnya merupakan tujuan pendidikan nasional. Manusia yang utuh adalah manusia yang seimbang antara kemampuan intelektual, sikap dan moral serta keterampilannya. Pengembang kurikulum berbasis kompetensi (KBK) harus memperhatikan ketiga keseimbangan itu.

c. Penguatan integritas nasional, Indonesia adalah negara yang terdiri dari berbagai suku dengan berbagai ragam latar belakang budayanya. Pendidikan harus dapat menanamkan penanaman penghargaan terhadap perkembangan budaya dan peradaban bangsa yang majemuk sehingga mampu memberikan sumbangan terhadap peradaban dunia.

d. Pengembangan ilmu pengetahuan dan teknologi informasi. Pengembangan kurikulum berbasis kompetensi (KBK) diarahkan agar anak didik memiliki kemampuan berpikir dan belajar dengan cara mengakses, memilih dan menilai pengetahuan untuk mengatasi situasi yang cepat berubah dan penuh tantangan melalui perkembangan ilmu pengetahuan dan teknologi informasi.

e. Pengembangan kecakapan hidup. Kecakapan hidup mencakup keterampilan diri (personal skills), keterampilan berpikir rasional (thinkings skills), keterampilan sosial (social skills), keterampilan akademik (academic skills), keterampilan vokasional (vocational skills). Kurikulum mengembangkan kecakapan hidup melalui pembudayaan membaca, menulis, berhitung, sikap dan perilaku adaptif, kreatif, kooperatif dan kompetitif.

f. Berpijak pada empat pilar pendidikan.Kurikulum berbasis kompetensi (KBK) mengkoordinasikan fondasi belajar kepada empat pilar pendidikan, yaitu: (1) belajar untuk memahami (learning to know), (2) belajar untuk berbuat kreatif (learning to do), (3) belajar untuk hidup dalam 
kebersamaan (learning to life together), dan (4) belajar untuk membangun dan mengekspresikan jati diri (learning to be).

g. Komprehensif dan berkesinambungan. Komprehensif mencakup keseluruhan dimensi kemampuan dan substansi yang disajikan secara berkesinambungan mulai dari usia Taman Kanak-Kanak sampai dengan pendidikan menengah. Kemampuan mencakup pengetahuan, keterampilan, nilai dan konsep serta fenomena yang berkembang di masyarakat.

h. Belajar sepanjang hayat. Pendidikan diarahkan pada proses pembudayaan dan pemberdayaan peserta didik yang berlanjut sepanjang hayat. $^{5}$

Di samping prinsip-prinsip pengembangan di atas, kurikulum berbasis kompetensi (KBK) juga didasarkan pada prinsip-prinsip pelaksanaan sebagai berikut:

a) Diversifikasi kurikulum. Kurikulum berbasis kompetensi (KBK) dikembangkan dengan prinsip diversifikasi sesuai dengan satuan pendidikan, potensi daerah, dan peserta didik.

b) Kesamaan dalam memperoleh kesempatan. Prinsip ini mengandung pengertian bahwa melalui kurikulum berbasis kompetensi (KBK) penyediaan tempat yang memberdayakan semua peserta didik secara demokratis dan berkeadilan untuk memperoleh pengetahuan, keterampilan dan sikap diutamakan. Seluruh peserta didik dari berbagai kelompok seperti kelompok kurang mampu secara ekonomis, kelompok yang memerlukan bantuan khusus, kelompok berbakat dan unggul berhak menerima pendidikan tepat sesuai dengan kemampuan dan kecepatannya.

c) Berpusat pada anak. Upaya memandirikan peserta didik untuk belajar, bekerja sama dan menilai diri sendiri diutamakan agar peserta didik mampu membangun kemauan, pemahaman dan pengetahuannya. Peningkatan potensi, kecerdasan dan minat peserta didik perlu terus

${ }^{5}$ Nurhadi, Pembelajaran Kontekstual dan Penerapannya dalam KBK (Malang: Universitas Negeri Malang, 2004), hlm. 83. 
menerus diupayakan. Penilaian berkelanjutan komprehensif menjadi sangat penting dalam rangka pencapaian usaha tersebut. Penyajiannya disesuaikan dengan tahap-tahap perkembangan anak didik melalui, "pembelajaran akitf, kreatif efektif dan menyenangkan (PAKEM)".

d) Pendekatan menyeluruh dan kemitraan. Semua pengalaman belajar dirancang secara menyeluruh dan berkesinambungan mulai dari Taman Kanak-Kanak sampai tingkat menengah. Keberhasilan pencapaian pengalaman belajar menuntut kemitraan dan tanggung jawab besama dari peserta didik, guru, sekolah/madrasah, orang tua, perguruan tinggi, dunia usaha dan industri dan masyarakat secara umum.

e) Kesatuan dalam kbijakan dan keragaman dalam pelaksanaan. Standar kompetensi dalam kurikulum berbasis kompetensi (KBK) disusun pusat, namun cara pelaksanaannya disesuaikan dengan kebutuhan dan kemampuan masing-masing daerah atau sekolah/madrasah. Standar kompetensi dapat dijadikan acuan penyusunan kurikulum berdiversifikasi berdasarkan pada satuan pendidikan, potensi daerah, peserta didik serta taraf internasional. ${ }^{6}$

Khusus untuk lembaga pendidikan madrasah (Lembaga Pendidikan yang bernaung di bawah Kementerian Agama), ada satu prinsip lagi dalam pelaksanaan kurikulum berbasis kompetensi (KBK) yaitu "Penciptaan suatu lingkungan yang Islami", ini dikarenakan madrasah merupakan lembaga pendidikan yang memiliki karakteristik ke-Islaman sehingga perlu diciptakan suatu kondisi yang kondusif yang bernuansa Islami. Nilai-nilai Islam diwujudkan dalam kehidupan keseharian madrasah. Penciptaan situasi Islami ini merupakan bagian dari diversifikasi dalam penerapan kurikulum berbasis kompetensi (KBK) kurikulum berbasis kompetensi (KBK) di Indonesia.

\section{Kurikulum Tahun 2006}

\section{Konsep Kurikulum Tahun 2006}

Tahun 2006, kurikulum dipahami sebagai seperangkat rencana dan pengaturan mengenai tujuan, isi, dan bahan pelajaran serta cara yang digunakan sebagai pedoman penyelenggaraan kegiatan pembelajaran untuk mencapai tujuan pendidikan tertentu, dengan terbitnya Peraturan

${ }^{6} /$ bid., h 4. 
Pemerintah Nomor 19 Tahun 2005, pemerintah telah menggiring pelaku pendidikan untuk mengimplementasikan kurikulum dalam bentuk kurikulum tingkat satuan pendidikan, yaitu kurikulum operasional yang disusun oleh dan dilaksanakan di setiap satuan pendidikan. ${ }^{7}$

Dalam standar nasional pendidikan (SNP Pasal 1, ayat 15) dikemukakan bahwa kurikulum tingkat satuan pendidikan (KTSP) adalah kurikulum operasional yang disusun dan dilaksanakan oleh masing-masing satuan pendidikan. Kurikulum tingkat satuan pendidikan (KTSP) disusun dan dikembangkan berdasarkan Undang-Undang No. 20 Tahun 2003 tentang Sistem Pendidikan Nasional pasal 36 ayat 1 dan 2 sebagai berikut:

a. Pengembangan kurikulum mengacu pada Standar Nasional Pendidikan untuk mewujudkan Tujuan Pendidikan Nasional.

b. Kurikulum pada semua jenjang dan jenis pendidikan dikembangkan dengan prinsip diversifikasi sesuai dengan satuan pendidikan, potensi daerah, dan peserta didik. ${ }^{8}$

Beberapa hal yang perlu dipahami dalam kaitannya dengan kurikulum tingkat satuan pendidikan (KTSP) adalah sebagai berikut:

a. Kurikulum tingkat satuan pendidikan (KTSP) dikembangkan sesuai dengan kondisi satuan pendidikan, potensi dan karakteristik daerah, serta sosial budaya masyarakat setempat dan peserta didik.

b. Sekolah dan komite sekolah mengembangkan kurikulum tingkat satuan pendidikan (KTSP) dan silabusnya berdasarkan kerangka dasar kurikulum dan standar kompetensi lulusan, di bawah supervisi dinas pendidikan kabupaten/kota, dan Departemen Agama yang bertanggung jawab di bidang pendidikan.

c. Kurikulum tingkat satuan pendidikan (KTSP) untuk setiap program studi di perguruan tinggi dikembangkan dan ditetapkan oleh masing-masing perguruan tinggi dengan mengacu pada Standar Nasional Pendidikan. ${ }^{9}$

${ }^{7}$ Masnur Muslich, Kurikulum Tingkat Satuan Pendidikan Dasar Pemahaman dan Pengembangan (Jakarta: Bumi Aksara, 2007), hlm. 11-16.

${ }^{8}$ Himpunan Peraturan Perundang-Undangan tentang Guru dan Dosen (Bandung: Fokus Media, 2006), hlm. 75. 
Asfiati

\section{Tujuan KTSP}

Secara umum tujuan diterapkannya kurikulum tingkat satuan pendidikan (KTSP) adalah untuk memandirikan dan memberdayakan satuan pendidikan melalui pemberian kewenangan (otonomi) kepada lembaga pendidikan dan mendorong sekolah untuk melakukan pengambilan keputusan secara partisipatif dalam pengembangan kurikulum. Secara khusus tujuan diterapkannya kurikulum tingkat satuan pendidikan (KTSP) adalah untuk:

a. Meningkatkan mutu pendidikan melalui kemandirian dan inisiatif sekolah dalam mengembangkan kurikulum, mengelola dan memberdayakan sumberdaya yang tersedia.

b. Meningkatkan kepedulian warga sekolah dan masyarakat dalam pengembangan kurikulum melalui pengambilan keputusan bersama.

c. Meningkatkan kompetisi yang sehat antar satuan pendidikan tentang kualitas pendidikan yang akan dicapai. ${ }^{10}$

Memahami tujuan kurikulum tingkat satuan pendidikan (KTSP) dapat dipandang perlu sebagai suatu pola pendekatan baru dalam pengembangan kurikulum dalam konteks otonomi daerah yang sedang digulirkan dewasa ini. Oleh karena itu, kurikulum tingkat satuan pendidikan (KTSP) perlu diterapkan oleh setiap satuan pendidikan, terutama berkaitan dengan tujuh hal sebagai berikut:

a. Sekolah lebih mengetahui kekuatan, kelemahan, peluang, dan ancaman bagi dirinya sehingga dia dapat mengoptimalkan pemanfaatan sumberdaya yang tersedia untuk memajukan lembaganya.

b. Sekolah lebih mengetahui kebutuhan lembaganya, khususnya input pendidikan yang akan dikembangkan dan didayagunakan dalam proses pendidikan sesuai dengan tingkat perkembangan dan kebutuhan peserta didik.11

${ }^{9}$ E. Mulyasa, Kurikulum Tingkat Satuan Pendidikan (Bandung: Rosdakarya, 2006), hlm. 20.
${ }^{10} / \mathrm{bid}$.
${ }^{11} / \mathrm{bid}$. 
c. Pengambilan keputusan yang dilakukan oleh sekolah lebih cocok untuk memenuhi kebutuhan sekolah karena pihak sekolahlah yang paling tahu apa yang terbaik bagi sekolahnya.

d. Keterlibatan semua warga sekolah dan masyarakat dalam pengembangan kurikulum menciptakan transparansi dan demokrasi yang sehat, serta lebih efisien dan efektif bilamana dikontrol oleh masyarakat setempat.

e. Sekolah dapat bertanggung jawab tentang mutu pendidikan masingmasing kepada pemerintah, orang tua peserta didik, dan masyarakat pada umunya, sehingga dia akan berupaya semaksimal mungkin untuk melaksanakan dan mencapai sasaran kurikulum tingkat satuan pendidikan (KTSP).

f. Sekolah dapat melakukan persaingan yang sehat dengan sekolahsekolah lain untuk meningkatkan mutu pendidikan melalui upaya-upaya inovatif dengan dukungan orang tua peserta didik, masyarakat dan pemerintah daerah setempat.

g. Sekolah dapat secara cepat merespon aspirasi masyarakat dan lingkungan yang berubah dengan cepat, serta mengakomodasinya dalam kurikulum tingkat satuan pendidikan (KTSP). ${ }^{12}$

\section{Kurikulum Tahun 2013 KPKB}

\section{Konsep Kurikulum Tahun 2013 KPKB}

Tahun 2013, sebelum mengenal lebih rinci tentang kurikulum 2013 penting juga kiranya memaparkan hal-hal yang terlingkup di dalam kurikulum 2013 khususnya tentang pendidikan agama Islam sebagai salah satu esensi yang menonjol dalam kurikulum 2013. Diberlakukan kurikulum 2013 merupakan respons atas berbagai kondisi bangsa yang terjadi akhirakhir ini. Kementerian Pendidikan dan Kebudayaan menyebutkan bahwa kurikulum 2013 adalah jawaban atas ancaman disintegrasi bangsa yang mewujud dalam berbagai pertikaian, kerusuhan, demonstrasi anarkis, gerakan separatis serta berbagai tragedi lainnya yang menghiasi perjalanan

\footnotetext{
${ }^{12} /$ bid.
} 
Asfiati

negeri ini. Upaya dalam mengejar ketertinggalan bangsa bidang pendidikan dipandang perlu untuk memperbaharui kurikulum.

Hasil penelitian yang dilakukan secara internasional menunjukkan bahwa Indonesia berada di urutan kelima dari bawah, di atas Qatar, Kuwait, Maroko dan Afrika Utara, bidang kemampuan baca siswa tingkat Sekolah Dasar. PIRLS (Progress in International Reading Literacy Study) yang mengkaji tentang PISA (Programme for International Student Assessment) melakukan penelitian secara berkala untuk siswa sekolah menengah pertama (SMP) dan sekolah menengah atas (SMA) dalam reading literacy, mathematics literacy, dan scientific literacy, dalam ketiga hal tersebut Indonesia berada dalam kelompok bawah, demikian juga penelitian yang dilakukan TIMMS (Trends in International Matematics and Science Study) menunjukan hal yang sama bahwa siswa Indonesia menduduki posisi bawah, bahkan secara relatif menunjukan penurunan. ${ }^{13}$

Kondisi ini jelas menimbulkan keprihatinan dan sekaligus dorongan untuk terus berupaya meningkatkan mutu pendidikan. Untuk itu pemerintah melalui berbagai kebijakan, baik terkait dengan sarana prasarana, tenaga pendidikan, maupun kurikulum yang belakangan ini menjadi trend pendidikan persekolahan di Indonesia memperbaiki proses pendidikan dengan melahirkan kurikulum 2013. Kurikulum 2013 pada dasarnya merupakan upaya untuk memperbaiki proses pendidikan/pembelajaran pada jalur pendidikan formal atau sekolah serta memperhatikan kualitas dan spritual.

Bila ditilik berdasarkan pendidikan agama Islam melalui kurikulum 2013, jiwa generasi baru diharapkan makin nasionalis, ink/usif, menghargai perbedaan, beretika dalam menyampaikan pendapat, serta mengamalkan berbagai karakter mulia lainnya.

\section{Penutup}

Sebagai salah satu komponen pendidikan, kurikulum sangat strategis digunakan sebagai pedoman penyelenggaraan kegiatan pembelajaran

${ }^{13}$ McNeil\&John D, Contemporary Curriculum(New York: John Willey \& Son, 2006), hlm.1. 
untuk mencapai tujuan pendidikan tertentu. Dimaksudkan bahwa di dalam kurikulum terdapat panduan interaksi antara guru dan peserta didik. Dengan demikian, kurikulum berfungsi sebagai nafas atau inti dari proses pendidikan di sekolah untuk memberdayakan potensi peserta didik dengan mengedepankan nilai-nilai ajaran agama Islam.

Perkembangan dan pengembangan kurikulum pendidikan agama Islam secara popular mengacu pada perubahan bidang dan materi pelajaran serta perubahan waktu, esensi kurikulum dalam aspek tujuan makro pendidikan. Kurikulum Pendidikan agama Islam dalam konteks penalaran dimulai dari hal-hal yang bersifat nilai-nilai luhur dalam kehidupan sehari-hari kemudian bergerak ke hal-hal yang bersifat terapan dalam norma-norma kehidupan sehari-hari itu sendiri. Disimpulkan bahwa sudah tentu memerlukan kesiapan peserta didik dan pendidik dalam menjalankan alur pembelajaran.

Demikian adanya dengan pasca Undang-Undang Sistem Pendidikan Nasional No 20 Tahun 2003 yang menitikberatkan pada:

a. Pengembangkan keseimbangan antara pengembangan sikap spiritual dan sosial, rasa ingin tahu, kreativitas, kerja sama dengan kemampuan intelektual dan psikomotorik;

b. Madrasah merupakan bagian dari masyarakat yang memberikan pengalaman belajar terencana dimana peserta didik menerapkan apa yang dipelajari di sekolah ke masyarakat dan memanfaatkan masyarakat sebagai sumber belajar;

c. Mengembangkan sikap, pengetahuan, dan keterampilan serta menerapkannya dalam berbagai situasi di madrasah dan masyarakat;

d. Memberi waktu yang cukup leluasa untuk mengembangkan berbagai sikap, pengetahuan, dan keterampilan;

e. Kompetensi dinyatakan dalam bentuk kompetensi inti kelas yang dirinci lebih lanjut dalam kompetensi dasar mata pelajaran;

f. Kompetensi inti kelas menjadi unsur pengorganisasi (organizing elements) kompetensi dasar, di mana semua kompetensi dasar dan proses pembelajaran dikembangkan untuk mencapai kompetensi yang dinyatakan dalam kompetensi inti; 
g. Kompetensi dasar dikembangkan didasarkan pada prinsip akumulatif, saling memperkuat (reinforced) dan memperkaya (enriched) antar mata pelajaran dan jenjang pendidikan (organisasi horizontal dan vertikal).

Sasaran tersebut guna mempersiapkan manusia Indonesia agar memiliki kemampuan hidup sebagai pribadi dan warga negara yang beriman, produktif, kreatif, inovatif, dan afektif serta mampu berkontribusi pada kehidupan bermasyarakat, berbangsa, bernegara, dan peradaban dunia.

Kurikulum pendidikan agama Islam Pasca Undang-Undang Sistem Pendidikan Nasional No 20 tahun 2003 ikut berperan penting dalam mengakui pentingnya pendidikan moral bangsa. Hal ini membuktikan bahwa Undang-Undang Sistem Pendidikan Nasional No 20 tahun 2003 ikut mengedepankan nilai-nilai kultural budaya berdasarkan nilai-nilai moral dan kaedah-kaedah yang berketuhanan Yang Maha Esa.

\section{Daftar Pustaka}

Abdul Majid dan Dian Andayani, Pendidikan Karakter Perspektif Islam Bandung: Remaja Rosdakarya, 2012.

Departemen Agama RI, Direktorat Jenderal Kelembagaan Agama Islam, Memahami Paradigma Baru Pendidikan Nasional dalam UndangUndang Sisdiknas Jakarta: Depag Rl, 2003.

Direktorat Pendidikan Madrasah Direktorat Jenderal Pendidikan Islam Kementerian Agama Republik Indonesia, Modul Inti Panduan Pengembangan Kurikulum Madrasah 2013 Jakarta: Australian Aid Kemitraan Pendidikan Australia Indonesia, 2014.

E .Mulyasa, Kurikulum Tingkat Satuan Pendidikan Bandung: Rosdakarya, 2006.

------, Pengembangan dan Implementasi Kurikulum 2013 Bandung: Remaja Rosdakarya: 2013.

Himpunan Peraturan Perundang-Undangan tentang Guru dan Dosen Bandung: Fokus Media, 2006. 
Kementerian Agama Provinsi Sumatera Utara, Keputusan Direktur Jenderal Pendidikan Islam Nomor: 2676 Tahun 2013 Tentang Kurikulum 2013 Mata Pelajaran Pendidikan Agama Islam dan Bahasa Arab di Madrasah Medan: Kementerian Agama Provinsi Sumatera Utara, 2014.

Masnur Muslich, Kurikulum Tingkat Satuan Pendidikan Dasar Pemahaman dan Pengembangan Jakarta: Bumi Aksara, 2007.

McNeil\&John D, Contemporary Curriculum New York: John Willey \& Son, 2006.

Nurhadi, Pembelajaran Kontekstual dan Penerapannya dalam KBK Malang: Universitas Negeri Malang, 2004.

Zainuddin, Reformasi Pendidikan Kritik Kurikulum dan Manajemen Berbasis Sekolah Yogyakarta: Pustaka Pelajar, 2008. 